\title{
IDENTIFICATION, EXPRESSION AND LOCALIZATION OF THE UL45 PROTEIN OF EQUINE HERPES VIRUS TYPE 1
}

Samy Kasem ${ }^{1}$, Gabr Albagory ${ }^{2}$, Ali Abdelkader ${ }^{3}$, Hideto Fukushi ${ }^{4}$, Noura Alkhalefa $^{1,4}$, Mohamed Nayel $^{5}$, Al-Said Dawod $^{6}$, Tarek Kamal ${ }^{7}$

${ }^{1}$ Department of Virology, Faculty of Veterinary Medicine, kafrelsheikh University, kafrelsheikh, 33516, Egypt

${ }^{2}$ Department of Virology, Faculty of Veterinary Medicine, Benha University, Egypt

${ }^{3}$ Department of Anatomy, Faculty of Veterinary Medicine, kafrelsheikh University, kafrelsheikh, 33516, Egypt

${ }^{4}$ Department of Veterinary Microbiology, Faculty of Applied Biological Sciences, Gifu University, Gifu 501-1193, Japan

${ }^{5}$ Department of Animal Medicine and Infectious Diseases, Faculty of Veterinary Medicine, Sadat City University, Sadat City, Egypt

${ }^{6}$ Animal research institute, Kafrelsheikh branch, El Geish Street, Kafrelsheikh, Egypt.

${ }^{7}$ Department of Biochemistry, Faculty of Veterinary Medicine, kafrelsheikh University, kafrelsheikh, 33516, Egypt

\section{ABSTRACT}

UL45 was one of the tegument proteins that have been identified in both EHV-1 and EHV-4, it was recorded that ORF 15 EHV-lwas homologues to UL45 (HSV). Until now, the function of UL45 protein in cell culture and animal models is poorly understood. To investigate the function of the UL45 protein, we expressed the UL45 gene in prokaryotic expression vector $p G E X-6 P-1$ to express UL45 protein and used the resulting protein to raise guinea pig antiserum. In western blotting experiments, the antiserum directed against the $\mathrm{N}$ terminal of EHV-1 ULA5 protein specifically recognized a protein with molecular weight ranging from 30 to $60 \mathrm{kDa}$ in the infected cells lysates. The immunofluorescence assay also showed that EHV-1 ORF15 antiserum was able to probe the UL45 protein which is localized mainly in the cytoplasm associating with the membrane of the cells infected with EHV-1 Ab4p.

Keywords: Equine herpes virus -1 (EHV-1), UL45 protein, Protein expression, Polyclonal antibody, Immunofluorescence assay 


\section{INTRODUCTION}

EHV-1 is a viral pathogen with a high prevalence in domestic horses worldwide (Allen et al., 1999). EHV-1 infection has enormous economic impact on the breeding; competitive and recreational horse industries, as losses through abortion, respiratory disease, neurological disorders and death of full-term newborns occur perennially.

Herpes viruses are among the largest and most complex family of viruses (Davison \& Clements, 2004). Their virions are 200-250 $\mathrm{nm}$ in diameter and consist of a linear double-stranded DNA genome of 125$245 \mathrm{kbp}$ packaged within an icosahedral capsid approximately $125 \mathrm{~nm}$ in diameter embedded in a matrix known as the tegument which contains many virus-coded proteins itself wrapped in a lipid membrane containing several viral glycoproteins (Davison 2002). Expression of the viral genes occurs in a coordinately activated cascade fashion that consists of the sequential expression of immediate-early (IE), early (E), and late (L) genes (Khurana et al., 2010). The UL45 protein expresses at late times during EHV-1 infection. Dirk et al., (2001) reported that ORF15 encodes a glycosyslated type II transmembrane proteins and that is involved in virus egress. Deletion of the ORF15 gene in EHV-1 strains RacL22 and $\mathrm{RacH}$ reduced the virus's replication in vitro, indicating that the gene is not essential for virus replication in cultured cells. UL45 of other herpesviruses, insertion of a marker gene into UL45 genes of HSV-1 or FHV- 1 demonstrated that a UL45 product is not essential for replication of these viruses. While the HSV-1 mutant exhibited an influence on the plaque phenotype.

To begin addressing questions regarding UL45function and regulation, we have raised antiserum that recognizes the UL45protein and have studied its localization and kinetics of expression and the contribution of various UL45 transcripts to its synthesis. 


\section{MATERIALS AND METHODS}

\section{1-Viruses and cells}

EHV-1 Ab4p strain, which was kindly provided by Dr. A.J. Davison, Glasgow University, Scotland, was used. The virus was propagated in fetal equine kidney (FEK) cells. Other cells used in this study were Madin-Darby bovine kidney (MDBK) and Rabbit kidney 13 (RK-13) cells. All of these cells were cultivated with Eagle's minimum essential medium (EMEM) (Nissui, Tokyo, Japan) supplemented with $5-10 \%$ fetal bovine serum (FBS) and 100 units/ml penicillin and $100 \mu \mathrm{g} / \mathrm{ml}$ streptomycin.

\section{2- Construction of the plasmid expressing the UL45 protein}

The U145 gene of EHV-1 Ab4p strain was amplified by PCR using prime stare HS polymerase (Toyobo, Osaka, Japan) using the following primers: ORF15F with EcoR1 5-CTT GGA ATT CAT GGC AGG AGA CCC AAC A- 3 and ORF15R with Not15- TTT GCG GCC GCT TAC CGG GGA AAC GGT ATG A -3).The PCR programing was: initial denaturation at 94c for $5 \mathrm{~min}$, followed by 5 cycles consists of 3 temp $\left(98^{\circ} \mathrm{C}\right.$ for $10 \mathrm{sec}$, annealing at $48^{\circ} \mathrm{C}$ for $30 \mathrm{sec}$ and extension at $72^{\circ} \mathrm{C}$ for $30 \mathrm{sec}$ ), then 30 cycles of $98^{\circ} \mathrm{C}$ for $10 \mathrm{sec}, 58^{\circ} \mathrm{C}$ for $30 \mathrm{sec}, 72^{\circ} \mathrm{C}$ for $2 \mathrm{~min}$, followed by 1 cycle at $4^{\circ} \mathrm{C}$. The purified PCR product was digested with EcoRI and Not1 (Takara, Japan), and inserted into pGEX-6P-1 (GE Healthcare Bio-Sciences AB)) to generate a recombinant plasmid pGEX-6P-1 UL45. 


\section{3-Expression of the UL45 protein}

E. Coli BL21 was transformed with pGEX-6P-1 UL45 and the transformed one was inoculated into LB medium containing $50 \mu \mathrm{g} / \mathrm{ml}$ ampicillin and grown at $37^{\circ} \mathrm{C}$ over night. The culture was transferred to fresh $\mathrm{LB}$ medium and grown at $37^{\circ} \mathrm{C}$ until the OD600 reached about 0.5 . Then the recombinant protein expression was induced by isopropyl-D-thiogalactopyranoside (IPTG) at a final concentration of $0.1 \mathrm{mM}$. The total bacterial lysates were analyzed by SDS-PAGE (Laemmli 1970).

As a result of negative expression of the full length UL45 protein, couple of primers was designed for amplification of the $\mathrm{N}$ terminal of UL45. The full length of the $\mathrm{N}$ terminal of UL45 gene was $163 \mathrm{bp}$ and predicted to encode a protein of 50 amino acids, was amplified successfully from the pGEX-6P-1UL45 as a template using ORF15NF 5'- TAAGCGGCCGCATCGTGACTGAC- 3'and ORF15NR5'TGTTCTGCGTCGCTTTGTATAAACAAGCTCG- 3' primers. The PCR programing was:initial denaturation at $94^{\circ} \mathrm{C}$ for $5 \mathrm{~min}$,followed by 30 cycles consists of 3 temp $\left(98^{\circ} \mathrm{C}\right.$ for $10 \mathrm{sec}$, annealing at $60^{\circ} \mathrm{C}$ for $30 \mathrm{sec}$ and extension at $72^{\circ} \mathrm{C}$ for $2 \mathrm{~min}$. Final extension at $72^{\circ} \mathrm{C}$ for $7 \mathrm{~min}$, followed by 1 cycle at $4^{\circ} \mathrm{C}$. The PCR product was phosphorylated by the mean of the T4 polynucleotide kinase enzyme (Toyobo, Japan). To increase the yield, the expression of the UL45 protein was optimized as previously described (Pan et al., 2010) at different temperatures $\left(20{ }^{\circ} \mathrm{C}, 23^{\circ} \mathrm{C}, 25^{\circ} \mathrm{C}, 30^{\circ} \mathrm{C}\right.$ and $37^{\circ} \mathrm{C}$ ), different concentrations of IPTG $(0.1$ and $0.5 \mathrm{mM}$ ), and varying durations of induction (over night, $3 \mathrm{~h}$ and5 $\mathrm{h}$ ). Protein expression was assessed by $12 \%$ SDSPAGE. The solubility of the UL45 protein was analyzed as previously described (Pan et al., 2010). 


\section{4-Purification of UL45 protein}

The purification of UL45 protein was performed as previously described (Pan et al., 2010) To assess the solubility of the UL45 protein, logarithmic phase bacterial cultures were pelleted and suspended in lysis buffer and subjected to sonication on ice (about twelve sonication cycles 30x30sec) until clear. The total bacterial proteins were then partitioned into soluble and insoluble fractions by centrifugation at $14,000 \times \mathrm{g}$ for $15 \mathrm{~min}$ at $4{ }^{\circ} \mathrm{C}$. The supernatant (soluble fraction) was collected and the pellets (insoluble fraction). Both fractions were analyzed in parallel by $12 \%$ SDS-PAGE to characterize the solubility of the UL45 protein. The purification of the $\mathrm{N}$ terminal of UL45 Ab4p was performed using GS 4B beads (Glutathione sepharose beads) according to the manufacture instructions of GST Gene Fusion System (GE healthcare). After analysis by 12\% SDS-PAGE, the purified UL45 protein was quantified by Qubit Protein Assay Kit (Invitrogen) according to the manufacture instructions.

\section{5- Production of anti-EHV-1 UL45 specific polyclonal guinea pigs serum}

The fused proteins were purified by bounding to glutathione-Sepharose beads. The recombinant UL45 N terminal protein was isolated from the soluble fraction of the protein after repeated cycles of sonication and used to immunize 12 weeks females SPF guinea pigs (SLC Hertley Corporation- Japan). Animals were immunized with $100-\mu \mathrm{g}$ of the purified protein with equal amount of Titer Max® Gold adjuvant (Sigma Aldrich-USA). Sera collected before and after three intra muscular injections by applications of $100-\mu \mathrm{g}$ protein per 1 -week intervals, preliminary serum sample was collected from brachial 
vein, one week from the last injection for testing, and then the whole blood was collected from the immunized animal by heart puncture two weeks from the last injection. Food and water were freely available to the animals throughout the experiment and they observed for one week as a preliminary period. All animals were reared under the guidelines for animal experiments at Gifu University, faculty of applied biological science, Japan with approval by the committee of animal care and welfare.

\section{6-Western blotting}

Western blotting technique was preformed according to (Pan et al., 2010) briefly, FHK cells were infected at an MOI of 4 with the respective viruses Ab4p and Ab4p delta UL45 and cells were lysed at the indicated time points $40 \mathrm{hrs}$. p.i., by centrifugation at $15000 \mathrm{rpm}$ for $5 \mathrm{~min}$. The sample buffer containing $10 \%$ 2-mercaptoethanol was added. Samples were heated at $95^{\circ} \mathrm{C}$ for $5 \mathrm{~min}$, and proteins were separated on SDS $12 \%$ polyacrylamide gel. Separated proteins were blotted onto PVDF filters. Free binding sites on the PVDF membranes were blocked with 5\% non fat dry milk in PBS containing $0.005 \%$ Tween 20 (Sigma). Antibodies prepared against $\mathrm{N}$ terminal of UL45 were added at the indicated concentration (1:4000) for $1 \mathrm{hr}$ at RT, and after washing with PBST the membrane was incubated with peroxidase-conjugated goat anti-guinea pigs antibodies (Bethy 1) diluted 1:2000 in PBST, followed by ECL detection (Pharmacia-Amersham), and visualized by chemiluminescence (Amersham) recorded on X-ray films. 


\section{7-Indirect ImmunofluorescenceAssay (IFA).}

Immunofluorescence antibody technique was performed according to Armin et al., (2004), with the modification in the dilution of the anti bodies prepared in this study, briefly,RK-13 cells $40-50 \%$ monolayer were infected with EHV-1 Ab4p virus at $(\mathrm{MOI}=4)$ in 24 well plate at specific time point (0- 4-6-8-10 hrs, and over night).The cells then fixed with $250 \mu$ of ice cold $4 \%$ paraformaldehyde at $\mathrm{RT}$ for $15 \mathrm{~min}$ on bio shaker, after discarding of the paraformaldehyde, the cell were washed 3 times with 1 XPBS. Adding $250 \mu \mathrm{l}$ of $50 \mathrm{mM}$ NH4CL for each well and incubate at RT for $10 \mathrm{~min}$ on bio shaker discard the NH4CL and add $240 \mu \mathrm{l}$ of $0.2 \%$ triton $100 \mathrm{x}$ for $10 \mathrm{~min}$ at RT on bio shaker, then the cells were blocked by $250 \mu$ of $3 \%$ BSA/PBST for 30 min at RT. The cells running with 3 rounds of washing then incubated with 1 st antibody (purified poly clonal antibodies prepared against UL45 gene in this study) which diluted 1/500 in $0.005 \%$ PBST for $1 \mathrm{hr}$ at $37^{\circ} \mathrm{C}$ in $\operatorname{co} 2$ incubator. Washing 3 times with $0.005 \%$ PBST. The cells then incubated with the 2ndantibody FITC conjugated goat anti guinea pig IgG (sigma Aldrich, USA) diluted $1 / 200$ in PBST for $1 \mathrm{hr}$ in $37^{\circ} \mathrm{C}$ incubator, after discarding the 2nd antibody, the cell were washed with $0.005 \%$ PBST, and the slides were mounted with slow fade anti fade reagent. The fixed cells were analyzed by fluorescence microscopy (Axiovert/Zeiss). 


\section{RESULTS}

\section{1-Construction of the Ul45 prokaryotic expression plasmid}

After extraction of the DNA of EHV-1 Ab4p strain virus, the purified DNA was used for amplification of the target sequence of the ORF 15 using the PCR technique. Many trials for adjustment the annealing temperature of the designed primers for PCR programming, as a result the full-length UL45 gene, which is composed of $659 \mathrm{bp}$ (base pairs) in addition to the restriction site for both EcoRI andNot1 digestive enzymes and digestive nucleotides, which predicted to encode a protein of 219 amino acids, giving rise to $705 \mathrm{bp}$ PCR product which amplified successfully from the EHV-1 (strain Ab4p) genome (Fig 1A), indicated by only one clear specific band at the expected target length. After obtaining specific PCR product of the UL45 gene, it was ligated with the purified plasmid pGEX-6P-1 after digestion with the restriction enzymes (EcoRI andNot1), and transformed in BL21 E coli, in order to obtain positive colonies carrying the recombinant plasmid. The selected original colonies, which give positive reaction, were plated for the second time for obtaining single colonies on L.B agar plates containing ampicillin $(100 \mu \mathrm{g}$ $/ \mathrm{ml}$ ) and incubated at $37^{\circ} \mathrm{c}$ over night. Then, the recombinant plasmid was verified by colony PCR. The extracted DNA from single positive reacted colonies was digested with EcoRI andNot1 giving raise to the correct insertion and recombination indicated by two clear bands, one referred to the pGEX-6P-1 of molecular size $4984 \mathrm{bp}$, and the $2^{\text {nd }}$ band of $705 \mathrm{bp}$ of the exact length of the inserted fragment (Fig 1B). The sequencing result showed that there was no mutation of amino acid sequences of the recombinant plasmid. 
(A)

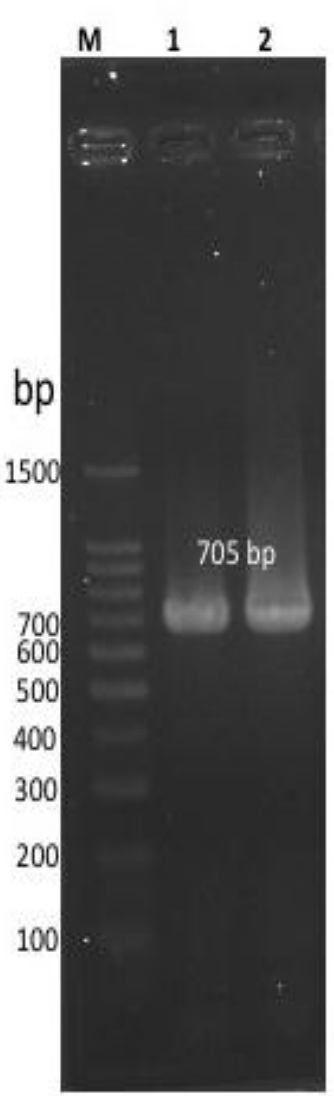

(B)

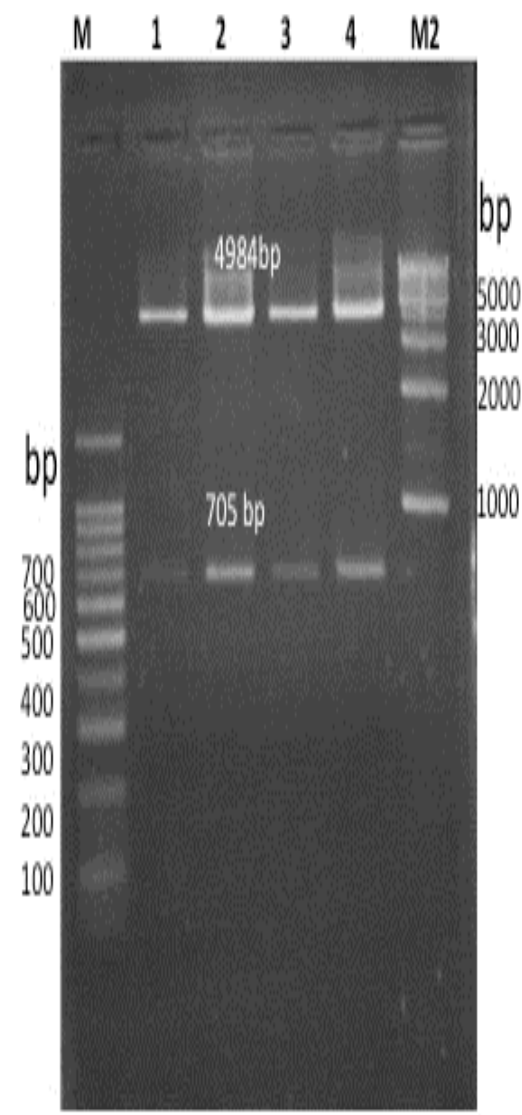

(C)

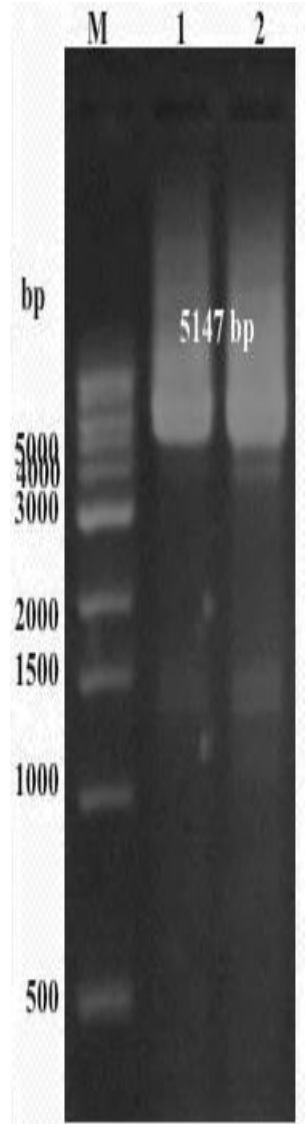

Fig (1): Construction of the recombinant plasmid expressing the UL45.(A) Lane 1,2PCR amplification of the full-length UL45gene fromAb4p EHV-1 DNA. (B) Lane1-4 Restriction enzyme digestion of the positively reacted selected single colonies harboring the recombinant plasmid pGEX-6P-1UL45 DNA with EcoRI and Not1; (C) Construction of the pGEX-6P1UL45 $\mathrm{N}$ terminus plasmid using pGEX-6P-1UL45 DNA as a template; Lane1, 2 amplifiedpGEX-6P-1UL45 $\mathrm{N}$ terminus. Lane M: 100 bp DNA ladder, and M2: 1kb DNA ladder 


\section{2-Expression of the UL45 protein}

After induction with different concentrations of IPTG $(0.1$ and $0.5 \mathrm{mM})$ at different temperatures $\left(20,23,25,30\right.$ and $\left.37^{\circ} \mathrm{C}\right)$ with different incubation times (overnight, $3 \mathrm{hr}$, and $5 \mathrm{hr}$ ) it was found that the full length of U145 not expressed, so we make amplification of the $\mathrm{N}$ terminal of UL45 using recombinant pGEX-6P-1UL45 as a template, giving raise to specific band at expected size of $5247 \mathrm{bp}$ (Fig $1 \mathrm{C}$ ), then make recombination and expression of the $\mathrm{N}$ terminal at the same parameters for the full length UL45 gene in E. coli BL21.

Several expression parameters, including IPTG concentrations, induction temperatures and induction times were tested to optimize the expression of the U145 N terminal protein as previously described. It was found that E coli BL21 harboring pGEX-6P-1UL45 $\mathrm{N}$ terminal exhibited a high level of expression after induction with IPTG (Fig 2A and 2B). A distinct band of approximately $33.5 \mathrm{KDa}$, corresponding to the expected molecular weight of the UL45 $\mathrm{N}$ terminal protein, were found after induction with 0.1 and 0.5 mMIPTG at all times of incubation (Fig 2A)(Fig 2B) respectively, where as there was no expression of UL45 protein in BL21 harboring pGEX-6P-1UL45 $\mathrm{N}$ terminal without IPTG induction (Fig 2A, Lane 1). As a result, the recombinant protein was found to have the highest expression under the following condition, namely $0.1 \mathrm{mM}$ IPTG for $5 \mathrm{~h}$ at $37^{\circ} \mathrm{C}$ (Fig 2 A lane 8). 
Identification, Expression And Localization Of The U145 ...

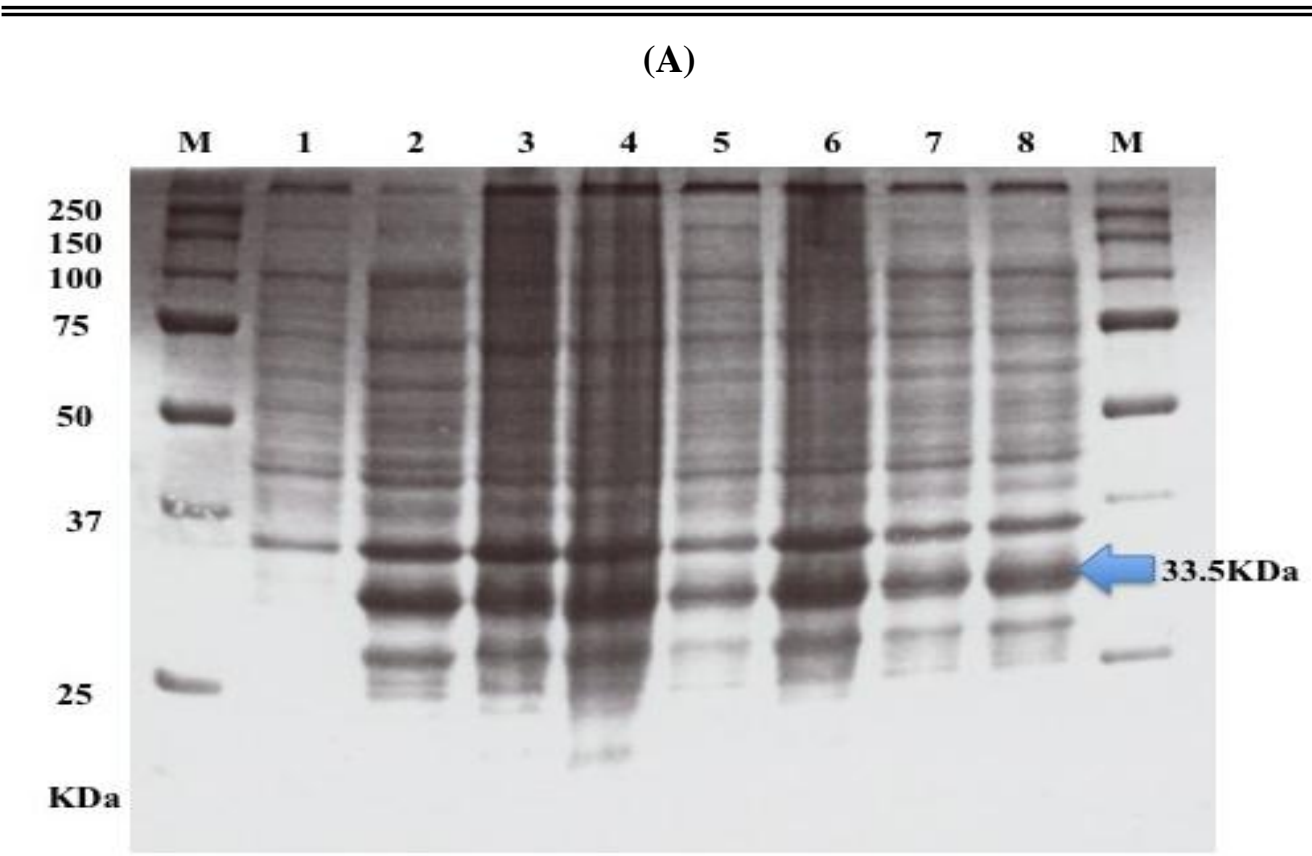

(B)

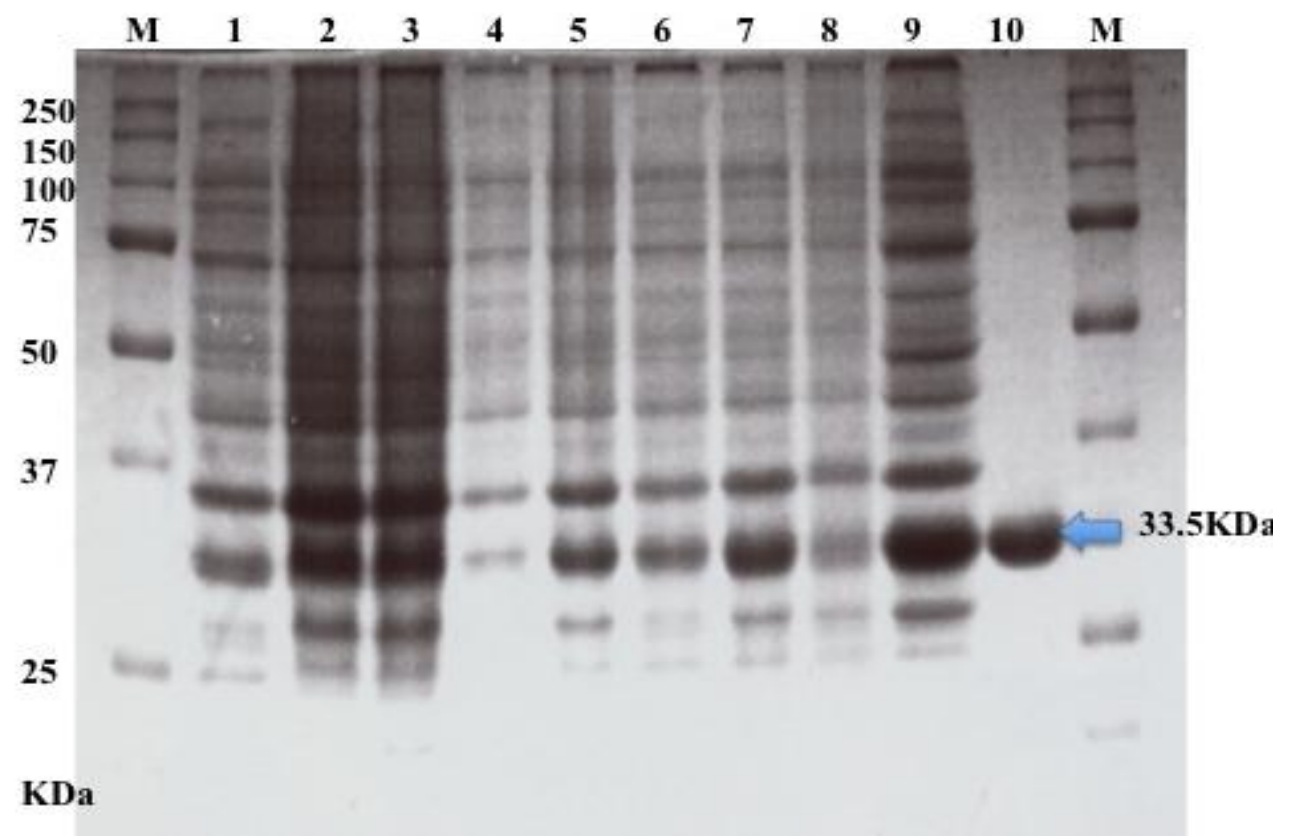

$\overline{\overline{\text { Kafrelsheikh Vet. Med. J. Vol. } 13 \text { No. } 1 \text { (2015) }}}$ 
Fig (2): Expression analysis and optimization of IPTG concentrations, induction temperatures and times. (A)SDS- PAGE analysis of $\begin{array}{llllllll}\text { expressed } & \text { UL45 } & \mathrm{N} & \text { terminus } & \text { protein using } & 0.1 & \mathrm{mM} & \text { IPTG }\end{array}$ concentrations, with different induction temperatures and times,lane 1; total protein from BL21 with pGEX-6P-1 UL45 $\mathrm{N}$ terminus before induction; lane 2-8, total protein from pGEX-6P-1 N UL45 transformed BL21 after induction at $20^{\circ} \mathrm{C}, 23^{\circ} \mathrm{C}, 25^{\circ} \mathrm{C}$ (over night), $30{ }^{\circ} \mathrm{C}$ for $3 \mathrm{hr}, 30^{\circ} \mathrm{C}$ for $5 \mathrm{hr}$ , $37^{\circ} \mathrm{C}$ for $3 \mathrm{hr}$ and $37^{\circ} \mathrm{C}$ for $5 \mathrm{hr}$, respectively. (B)SDS- PAGE analysis of the purification of the expressed UL45 N terminus protein, using $0.5 \mathrm{mM}$ IPTG concentrations, with different induction temperatures and times; lane 1-7, total protein from pGEX-6P-1 UL45 $\mathrm{N}$ terminus transformed BL21 after induction at $20^{\circ} \mathrm{C}, 23^{\circ} \mathrm{C}, 25^{\circ} \mathrm{C}$ (over night), $30{ }^{\circ} \mathrm{C}$ for $3 \mathrm{hrs}$, $30^{\circ} \mathrm{C}$ for $5 \mathrm{hrs}, 37^{\circ} \mathrm{C}$ for $3 \mathrm{hrs}$ and $37^{\circ} \mathrm{C}$ for $5 \mathrm{hrs}$, respectively; lane 8, insoluble fractions (pellet); lane 9, soluble fractions (supernatant); lane 10, the purified UL45 $\mathrm{N}$ terminus protein. Lane M: molecular weight protein maker (KDa).

\section{3-Purification of the UL45 protein}

According to the SDS-PAGE analysis of the soluble fraction and cell debris pellet of the expressed recombinant protein after several rounds of sonication and centrifugation, the majority of the induced protein was found in the supernatant (Fig 2B, lane 9).Suggesting that the UL45 protein was soluble. 
Purification of the $\mathrm{N}$ terminus UL45 Ab4p protein was performed with GS 4B. The SDS-PAGE analysis of the purified protein sample showed that the target protein could be conjugated successfully to the Glutathione sepharose beads, and a single target band corresponding to the correct molecular weight $(33.5 \mathrm{kDa})$ of the expected protein was detected without contamination of other bacterial proteins (Fig 2B, lane 10).

After purification, the UL45 protein was quantified. The result showed that the concentration of the purified UL45 protein was $1.3 \mathrm{mg} / \mathrm{ml}$.

\section{4-Western blotting}

After three immunizations, the guinea pig antiserum was collected. Western blot results demonstrated that the anti-UL45 polyclonal antibody reacted with more than one band with apparent molecular masses ranging from (32 to $60 \mathrm{kDa}$ ) in fetal equine kidney cells infected with EHV-1 Ab4p strain (Fig 3, lane 3 ) at a dilution of 1:4000. In contrast, no band was detected in the lysate of the FHK cells infected with Ab4p delta UL45 (lane 4), mock infected fetal equine kidney cells, (lane, 2), and in the supernatant offetal equine kidney cells infected with EHV-1 Ab4p strain (purified virion) (lane 5), respectively. Moreover, the anti-UL45 polyclonal antibody could recognize the band with apparent molecular weight of $33.5 \mathrm{kDa}$ in lysate of $\mathrm{E}$. coli BL21 transformed with the plasmid pGEX-6P-1 UL45 after induction by $0.1 \mathrm{mM}$ IPTG at $37 \mathrm{c}$ for $5 \mathrm{~h}$ (Figure 4,lane 1) 


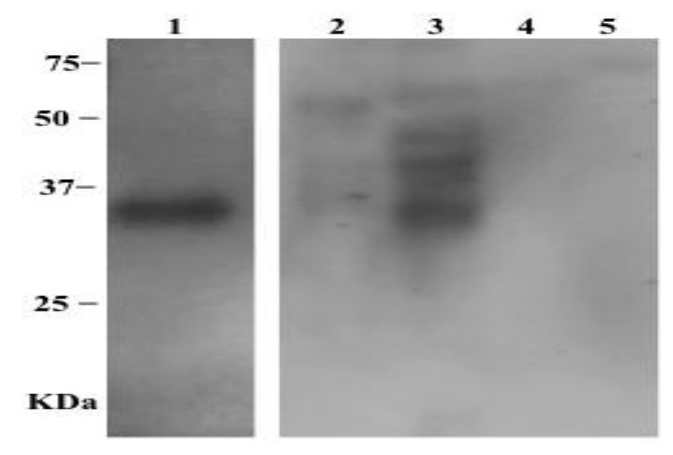

Fig (3): Western blot analysis of UL45 with guinea pig anti-UL45 polyclonal serum. Lane 1, total protein from E coli BL21 harboring the plasmid pGEX-6P-1 UL45 after induction by IPTG; Lane 2, lysate of mock FHK cells; Lane 3, the lysate of infected FHK cells with Ab4p virus, at moi of 4 and the cells were collected after $40 \mathrm{hrs}$ at $37{ }^{\circ} \mathrm{C}$ pi. Lane 4 , the lysate of FHK cells infected with delta U145 Ab4p virus; Lane 5, the supernatant of infected FHK cells with Ab4p virus (purified virion, at moi of 4.The protein maker $(\mathrm{kDa})$.

\section{5-Indirect immunofluorescence assay (IFA).}

Immunofluorescenceassay was applied on the Ab4p infected RK13 cells at moi of 4 for $24 \mathrm{~h}$, revealing that the intra cellular localization of U145 protein was in the cytoplasm mainly associated with the membrane of the infected cell in the form of distinct punctate speckles (Figure 4.S). On the other hand, no reactivity was detected in the mock cells. The time of UL45 protein expression was detected to be started at $8 \mathrm{~h}$ post infection and increase with the time, indicating high specificity and sensitivity of the prepared antibodies in detection of localization and time of expression of UL45 protein in the infected cells. 
Identification, Expression And Localization Of The U145 ...

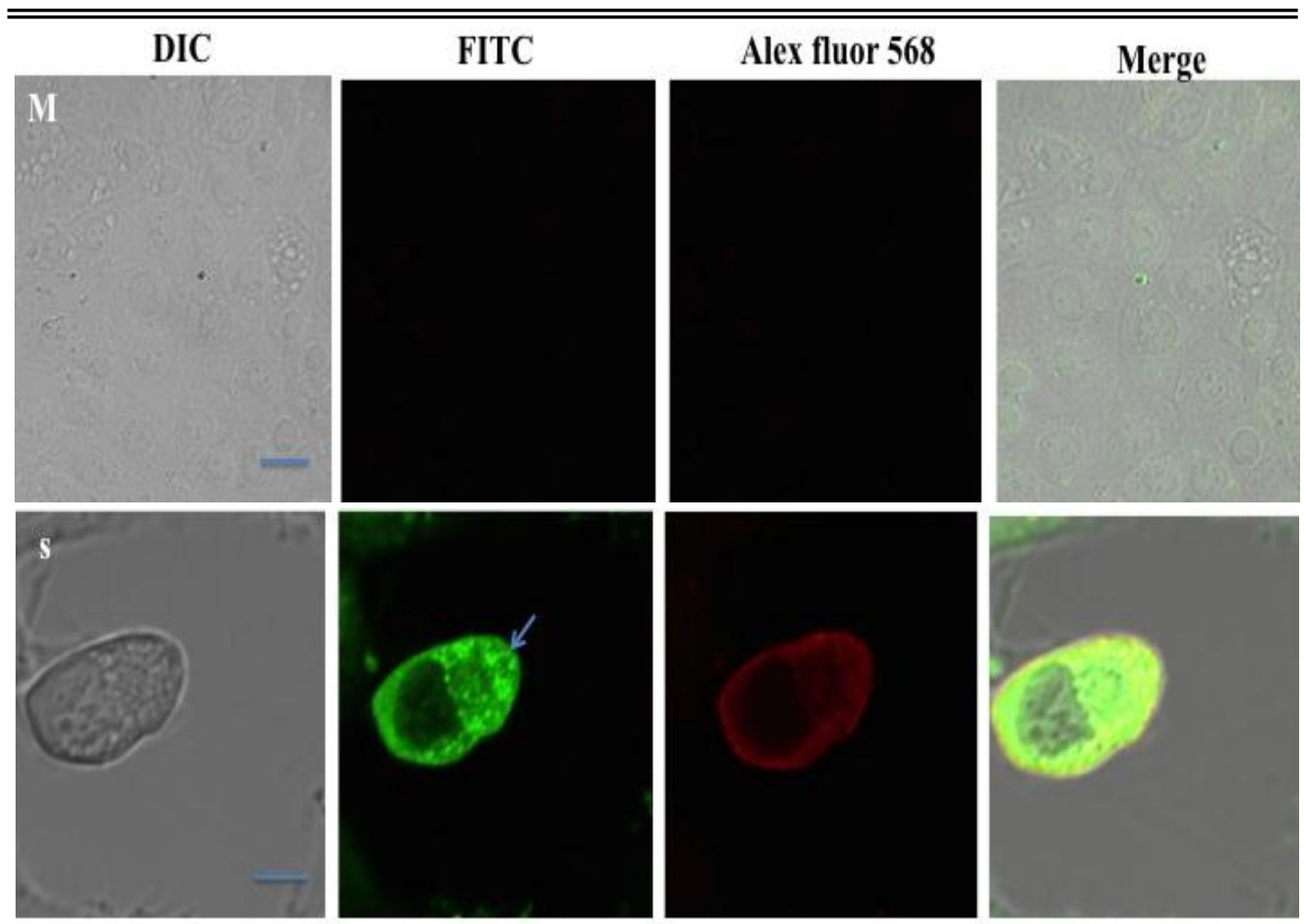

Fig (4): Indirect immunofluorescence assay of the UL45 protein in RK13 cells infected with EHV-1 Ab4p (M) Mock RK13 cells and (S) EHV-1 Ab4p infected RK13 cells $24 \mathrm{hr}$ pi, the cells were probed with the UL45 guinea pig serum for $1 \mathrm{hr}$ at $37 \mathrm{c}$ with HH-1 rabbit (1/1000 in PBST. then the cells were labeled with FITC-conjugated goat anti-guinea pig IgG, with Alexa anti rabbit antibodies Magnification bar, x20.

\section{DISCUSSION}

The recombinant proteins were the most common source of the diagnostic reagents and can be expressed in mammalian, insect and bacterial cells (Wei et al., 2008). While each of these systems has its advantages (Mayer and Buchner,2004), the 
bacterial expression system is one of the most universally used and has been employed widely due to multiple factors, including its relative inexpensive cost, ease of manipulation and rapid growth rate. However, different codon usage pattern in E. coli can cause diminished the production of heterologous eukaryotic protein. Many E. coli strains, such as BL21 Codon Plus and Rosetta-2 derived from BL21, are optimized to enhance expression of gene sequences that contain codons used rarely by E. coli (Gustafsson et al.,2004). Because there are many rare codons in the U145 gene, E. coli BL21, was used to optimize the expression of the fusion protein. If the exogenous gene had a high level of rare codon, then the efficiency of expression was usually low. The statistics of the UL45 gene codon usage condition showed that rare codon had a high usage frequency in UL45 gene, and this may be a reason of the UL45 gene expression failure. Besides, the bioinformatics of the transmembrance region analysis by application of TMHMM soft ware, showed that the 56-78 nucleotide sequence of UL45 protein was a membranespanning segment. As we know, the membrane-spanning segment was highly hydrophobic and not good for protein expression;the UL45 $\mathrm{N}$ terminus protein could be expressed in bacteria host, with a better expression in E. coli BL21. Additionally, different expression parameters were tested to optimize the expression, demonstrating that the UL45N terminal protein gained the highest expression under the condition of $0.1 \mathrm{mM}$ IPTG for $5 \mathrm{~h}$ at $37^{\circ} \mathrm{C}$ (Fig 2A). 
It is very common that high level expression of recombinant proteins in $E$. coli result in the formation of insoluble and inactive aggregate known as inclusion bodies (Oneda and Inouye 1999). In the present study, UL45 $\mathrm{N}$ terminus protein was found in the supernatant of the sonicated samples,indicating that the expressed protein was soluble.

In this study, to investigate the specificity of anti-UL45 polyclonal antibodies prepared in the guinea pigs, western blot technique was applied on both lysate and supernatant of FHK cells infected with Ab4p and Ab4p delta UL45 viruses, revealing that anti-UL45 polyclonal antibodies reacted specifically with four bands with apparent molecular masses ranging from (32 to $60 \mathrm{KDa}$ ) in the lysate of FHK cells infected with Ab4p for 40 h., which is consistent with previous reports (Dirk et al.,2001) who concluded that the EHV-1 UL45 protein is expressed as proteins of apparent Mrs of 32,000, 40,000, and 43,000 in infected cells. Moreover, with Western blot analysis without boiling and mercaptoethanol adding revealed additional proteins of $\mathrm{Mr}$ $60,000-90,000$ that reacted specifically with the UL45-His antibody.

IFA in infected cells confirmed the specificity of our UL45 polyclonal antibody, and it worked well, which may be special advantages of our antibody over those antibodies. The subcellular localization of a viral protein determines its function. The UL45 protein was a true late protein and a component of the virion from other herpesvirinae (Lembo et al., 2004). As expected, our results 
also demonstrate that the UL45 protein localizes in the cytoplasm of the infected cell mainly associated with the membrane. In addition, these results are in frame with the result obtained by Dirk et al., 2001, when make fractionation of the cellular element and studying the reactivity of the anti UL45 His antibody against the different fractions he found that the most reactivity was in the membrane fraction.

Early studies have demonstrated the function of UL45 protein as promoting the cell-cell fusion, anti-apoptosis, viral correct propagation, egress and keeping virulence of virus (Haanes et al.,1994). To further gain insight into the molecular mechanisms underlying the multiple functions of this protein, identification of cellular factors capable of interacting with the UL45 protein is necessary. Therefore, the anti-UL45 polyclonal antibody may serve as a useful tool for further study of UL45 interaction partners.

\section{REFERENCES}

- Allen, G. P., Kydd, J. H., Slater, J. D. \& Smith, K. C. (1999). Advances in understanding of the pathogenesis, epidemiology, and immunological control of equid herpes virus abortion. In Equine Infectious Diseases VIII. Proceedings of the Eighth International Conference, Dubai, 23-26 March, 1998, 1st edn, pp. 129-146. Edited by U. Wernery, J. F. Wade, J. A. Mumford \& O.-R. Kaaden. Newmarket: R \& W Publications. 
- Armin Baiker, Christoph Bagowski, Hideki Ito, Marvin Sommer, Leigh Zerboni, Klaus Fabel, John Hay, William Ruyechan, and Ann M. Arvin (2004). The Immediate-Early 63 Protein of Varicella-Zoster Virus: Analysis of Functional Domains Required for Replication In Vitro and for T-Cell and Skin Tropism in the SCIDhu Model In Vivo. Journal of Virology. p. 1181-1194 Vol. 78.

- Davison, A.J., (2002): Evolution of the herpes viruses. Veterinary Microbiology 86, 69-88.

- Davison, A. J. and Clements, J. B. (2004): Herpes viruses, general properties. In Topley and Wilson's Microbiology and Microbial Infections (Mahy, B.W.J. and ter Meulen, V., eds.), Hodder Arnold, London, pp. 488-506.

- Dirk Oettler, Oskar-Ruger Kaaden, and Antonie Neubauer (2001): The equine herpes virus 1 UL45 homology encodes a glycosylated type II transmemberane protein and is involved in virus egress .Virology 279, 302-312.

- Gustafsson C, Govindarajan S, Minshull J., (2004): Codon bias and heterologous protein expression. Trends Biotechnol, 22:346-353.

- Haanes, E. J. ab, Nelson, C. M. a, Soule, C. L. a, Goodman, J. L. $\boldsymbol{a}$, (1994): The UL45 gene product is required for herpes simplex virus type 1 glycoprotein B-induced fusion Journal of Virology .Volume 68, Issue 9, Pages 5825-583.

- Khurana S, Verma S, Verma N, Crevar CJ, Carter DM, Manischewitz J, King LR, Ross TM, Golding H. (2010): Properly folded bacterially expressed H1N1 hemagglutinin globular head and ectodomain vaccines protect ferrets against H1N1 pandemic influenza virus. PLoS One; 5: 548. 
- Laemmli U.K. (1970): Cleavage of structural proteins during the assembly of the head of bacteriophage T4. Nature 227(5259): 680-5.

- Lembo D, Donalisio M, Hofer A, Cornaglia M, Brune W, Koszinowski U, Thelander L, Landolfo S: (2004): The ribonucleotide reductase $\mathrm{R} 1$ homolog of murine cytomegalovirus is not a functional enzyme subunit but is required for pathogenesis. The Journal of Virology, 78:42784288.

- Mayer M, and Buchner, J., (2004): Refolding of inclusion body proteins .Method Mol Med, 94:239-254

- Oneda H, Inouye K., (1999): Refolding and recovery of recombinant human matrix metalloproteinase 7 (matrilysin) from inclusion bodies expressed by Escherichia coli. J Biochem, 126:905-911.

- Pan Weiwei, Xiaoming Ren, Hong Guo, Qiong Ding, Alan C. Zheng (2010): Expression, purification of herpes simplex virus type 1 UL4 protein, and production and characterization of UL4 polyclonal antibody. Journal of Virological Methods .Volume 163, Issue 2, Pages 465-469.

- Wei CJ, Xu L, Kong WP, Shi W, Canis K, Stevens J, Yang ZY, Dell A, Haslam SM, Wilson IA, Nabel GJ. (2008): Comparative efficacy of neutralizing antibodies elicited by recombinant hemagglutinin proteins from avian H5N1 influenza virus. J Virol, 82:6200-6208. 
تحديد وتعبير وتوطين البروتين رقم 15 لفيروس هربس الخيول نوع 1

د. سامى قاسم، أ.د. جبر الباجورى²، أ.د. على عبدالقادر1، أ.د. هيديتو فوكوشى³

د. نورا فيصل 1، د. محمد نايل4، د. السيد داود5'، د. طارق كمال1

\author{
1 كليه الطب البيطري جامعة كفر الثيخ، \\ كليه الطب البيطري جامعة بنها، \\ 3ليه (العلوم التطبيقيه جامعة جيفو ، \\ 4 كليه الطب البيطري جامعة مدينة السادات، \\ 5
}

الجين رقم 45 واحد من جينات غثاء التيجيومنت فى فيروسات الهربس ولقد تم تحديده فى

فيروسات هربس الخيول نوع 1 و4 رقم 15. ومازالت وظيفة هذا الجين غير معروفه، ولتجديد وظيفته فى الخلايا المصابه والحيوانات فقد تم تحميله على حامل لانتاج البروتين الخاص به. تم أستخدام هذا البروتين المنتج لتحديد وزنه والذى يترواح من 30 الى 60 كيلو دالتون فى الخلايا، وباستخدام أختبار الفلوريسين المناعى تم تحديد هذا البروتين مع سيتوبلازم الخلايا المصابه بفيروس هربس الخليول نوع 